\title{
Adaptability to submerged culture and amino acid contents of certain fleshy fungi common in Finland
}

\author{
Marja Liisa Hattula and H. G. Gyllenberg \\ Department of Microbiology, University of Helsinki, Finland
}

The literature on the possibilities of submerged culture of macrofungi is already voluminous. However, the interest has merely been restricted to the traditionally most valued fungi, particularly members of the genera Agaricus and Morchella (Humferd, 1948, 1952, Humfeld \& Sugihara, 1949, 1952, SuGIHARA \& Humfeld, 1954, Szuecs 1956, LitchField, 1964, 1967 a, b, Litchirield \& al., 1963). The information obtainable from studies on these organisms is not especially encouraging because the rate of biomass production seems to be too low to compete favourably with other alternatives of single cell protein production (LiTchField, $1967 \mathrm{a}, \mathrm{b}$ ). On the other hand, the traditional use of fungi as human food all over the world is a significant reason for continued research on the submerged production of fungal mycelium. If the fungal mycelium is comparable with other single-cell protein preparations as to its protein content and amino acid composition, it seems to gain preference over other alternatives due man's traditional knowledge and experience concerning the toxicity characteristics and other conditions influencing the edibility of fungi. A particular aspect requires attention in this connection. The traditional «mushroom« used as food concerns the fruiting bodies whereas the submerged cultivation produces preparations of mycelium. Therefore it seems that besides the adaptability to submerged growth the similarity in composition of the mycelial preparation to the corresponding fruiting bodies must be considered when the suitability of fungi for submerged production is evaluated. The present work concerns a collection of fungi common in Finland which have been investigated according to the criteria described above.

\section{MATERIAL}

The material consisted of 33 species of fungi, 29 of which were obtained from the Department of Silviculture, University of Helsinki, through the courtesy of Professor P. Mikola and Mr. O. Laiho. Four species were isolated by the present authors by taking a sterile piece of the fruiting body at the point where the cap and the stem are joined and by transferring it on a slant of suitable agar. The species considered are listed below following the nomenclature of $\mathrm{M}$. MOSER (1967). (For the species indicated by an asterisk fruiting bodies were collected for comparison whereas the species with the + label were isolated in pure culture by the present authors.)

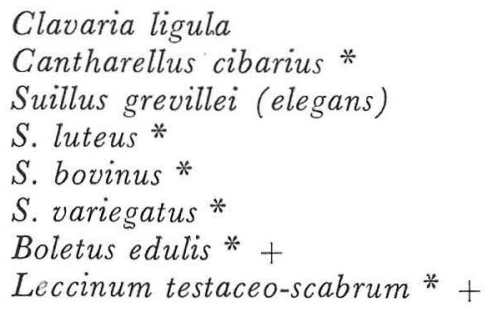


L. sp. ( Boletus versipellis $)$

L. scabrum *

Paxiltus incolutus *

$P$. atrotomentosus

Hygrophoropsis aurantiaca («Cantharellus a.«)

Tricholomopsis rutilans (Tricholoma r.)

Tricholoma flavobrunneum

T. imbricatum

Lyophyllum loricatum

Armillariella mellea (Armillaria m.) *

Collybia dryophila *

C. butyracea

Micromphale perforans (Marasmius p.)

Marasmius androsaceus

Macrolepiota procera (Lepiota p.)

Agaricus arvensis * +

Cystoderma amianthinum

Coprinus comatus * +

Hypholoma capnoides

Kuehneromyces mutabilis (Pholiota $\mathrm{m}$.)

Cortinarius hemitrichus

Lactarius repraesentaneus *

L. necator *

L. deliciosus aggr. *

L. rufus *

The pure cultures were maintained on Modess' agar the composition of which is the following (Modess, 1941): $\mathrm{KH}_{2} \mathrm{PO}_{4} 0.5 \mathrm{~g}, \mathrm{MgSO}_{4} \cdot 7 \mathrm{H}_{2} \mathrm{O}$ $0,5 \mathrm{~g}, \mathrm{NH}_{4} \mathrm{Cl} 0,5 \mathrm{~g}$, Malt extract $5 \mathrm{~g}$, Glucose $5 \mathrm{~g}$, $\mathrm{FeCl}_{3}, 1 \%$ sol. $0.5 \mathrm{ml}$, Agar. $15 \mathrm{~g}$, Distilled water $1000 \mathrm{ml}$. The medium was sterilized at $116^{\circ} \mathrm{C}$ for 20 minutes.

The mycelia were inoculated on new agar slants once a month and the tubes were kept four weeks at room temperature $\left(22-24^{\circ} \mathrm{C}\right)$ after which they were transferred to refrigerator temperature. For sixteen of the test organisms (indicated by in the above list) fruiting bodies were collected. These were cleaned of dust and sand by scraping and no water was used for cleaning. The fruiting bodies were cut into small pieces and dried at $40^{\circ} \mathrm{C}$ until they were easy to grind to fine powder. The powder was kept in a closed wessel in the refrigerator.

\section{RESULTS}

\section{Adaptability to submerged culture}

The adaptability to submerged culture was investigated by some experiments where the mycelia were grown on different media. The primary criterion in these experiments was how rapidly the fungi used the sugar in the medium. The first screening experiment to omit the most slowly growing species was made by growing the mycelia in the three following media:

a) $5 \%$ malt extract,

b) Modess' medium (Modess 1941),

c) Reusser's medium (REusser \& al., 1958) the composition of which is as follows:

Glucose $40 \mathrm{~g}$, Ammonium tartrate $8 \mathrm{~g}, \mathrm{KH}_{2} \mathrm{PO}_{4}$ $0.5 \mathrm{~g}, \mathrm{MgSo}_{4} \cdot 7 \mathrm{H}_{2} \mathrm{O} 0,5 \mathrm{~g}, \mathrm{CaCl}_{2} 50 \mathrm{mg}, \mathrm{FeSO}_{4} \cdot 7$ $\mathrm{H}_{2} \mathrm{O} 2 \mathrm{mg}, \mathrm{MnSO}_{3} \cdot \mathrm{H}_{2} \mathrm{O} 2 \mathrm{mg}$, Pyridoxine $1 \mathrm{mg}$, p-Aminobenzoic acid $1 \mathrm{mg}$, Thiamine $0.5 \mathrm{mg}$, Distilled water $1000 \mathrm{ml}$. The glucose was sterilized separately and the vitamins were added in separate solution which was sterilized by filtration. All three media were bottled in $250 \mathrm{ml}$ Erlenmeyer-flasks, $80 \mathrm{ml}$ in each, and they were sterilized at $116^{\circ} \mathrm{C}$ for 20 minutes.

The inoculation was made by transferring two agar slants of every species into $80 \mathrm{ml}$ $5 \%$ malt extract. The flasks were incubated 10 days at room temperature as stationary cultures. The grown mycelium was washed with sterile distilled water and was then broken by use of a sterile Ultra-Turraxmachine. The homogenized mycelium was suspended into $80 \mathrm{ml}$ of sterile water and 10 $\mathrm{ml}$ of this suspension was used to inoculate each flask. Because of the different amount of growth of the test organisms the suspensions employed as inocula were made visually as similar in density as possible. Every organism and medium was tested in duplicate. The flasks were incubated for two weeks in a rotary shaker $(200 \mathrm{rpm})$ at $28^{\circ} \mathrm{C}$. After this period the growth was scored visually. Table 1 shows the results of the experiment.

On the basis of the results of the experiment indicated in Table 1, the following species were omitted from further study: Paxillus involutus, P. atrotomentosus, Tricholoma flavobrunneum, Tricholomopsis rutilans, Lactarius repraesentaneus, L. deliciosus, Marasmius perforans, $M$. androsaceus, Cystoderma amianthinum, Boletus edulis and Boletus «versipellis«.

An experiment concerning the sugar consumption was made with the remaining species in order to evaluate the utilization of carbon and the ylield of mycelium per quantity of sugar used. Reusser's medium, which contains glucose, and Modess' medium, which contains maltose in addition to glucose, were 
Table 1. Submerged growth of fungi in different media. +++ growth excellent, ++ good growth, + weak grofth, - no growth (the amount mycelium equal to the inocolum).

\begin{tabular}{|c|c|c|c|}
\hline Species & 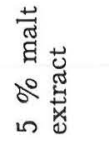 & 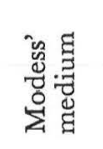 & 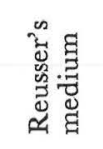 \\
\hline Clavaria ligula & ++ & +++ & +++ \\
\hline Cantharellus cibarius & +++ & +++ & +++ \\
\hline Suillus grevillei & ++ & ++ & ++ \\
\hline Suillus luteus & ++ & + & ++ \\
\hline Suillus bovinus & +++ & ++ & +++ \\
\hline Suillus variegatus & + & + & + \\
\hline Boletus edulis & - & + & + \\
\hline \multicolumn{2}{|c|}{ Leccinum testaceo-scabrum +++} & +++ & +++ \\
\hline «Boletus versipellis« & - & - & ++ \\
\hline Leccinum scabrum & - & ++ & ++ \\
\hline Paxillus involutus & + & + & + \\
\hline Paxillus atrotomentosus & - & - & $\cdots$ \\
\hline \multicolumn{4}{|l|}{ Hygrophoropsis } \\
\hline aurantiaca & ++ & + & + \\
\hline Tricholomopsis rutilans & 一 & -+ & ++ \\
\hline \multicolumn{4}{|l|}{ Tricholoma } \\
\hline flavobrunneum & - & + & -- \\
\hline Tricholoma imbricatum & - & ++ & - \\
\hline Lyophyllum loricatum & + & + & + \\
\hline Armillariella mellea & +++ & +++ & +++ \\
\hline Collybia dryophila & ++ & + & +++ \\
\hline Collybia butyracea & ++ & ++ & ++ \\
\hline Micromphale perforans & + & + & + \\
\hline Marasmius androsaceus & + & + & + \\
\hline Macrolepiota procera & ++ & ++ & ++ \\
\hline Agaricus arvensis & + & + & + \\
\hline Cystoderma amianthinum & $2++$ & - & - \\
\hline Coprinus comatus & + & + & + \\
\hline Hypholoma capnoides & ++ & ++ & + \\
\hline Kuehneromyces mutabilis & + & + & + \\
\hline Cortinarius hemitrichus & - & ++ & +++ \\
\hline Lactarius repraesentaneus & - & - & - \\
\hline Lactarius necator & ++ & ++ & ++ \\
\hline \multicolumn{4}{|l|}{ Lactarius deliciosus } \\
\hline aggr. & 一 & 一 & 一 \\
\hline Lactarius rufus & - & + & ++ \\
\hline
\end{tabular}

chosen for this experiment. Sugar determinations were made (a) before inoculation and (b) at the time the incubation was interrupted occording to the method of Bertrand (Grossfeld, 1935). A two weeks old stationary culture of mycelium was used as inoculum. The mycelium was broken by Ultra-Turrax into sterile water and $10 \mathrm{ml}$ of
Table 2. The efficiency of mycelium production, gram of mycelium/100 grams of sugar.
Mushroom

Cantharellus cibarius

Suillus grevillei

Suillus luteus

Suillus variegatus

Leccinum testaceo-scabrum

Leccinum scabrum

Hygrophoropsis aurantiaca

Tricholoma imbricatum

Lyophyllum loricatum

Armillariella mellea

Collybia dryophila

Macrolepiota procera

Agaricus arvensis

Coprinus comatus

Hypholoma capnoides

Kuehneromyces mutabilis

Cortinarius hemitrichus

Lactarius necator

Lactarius rufus

Clavaria ligula
Suillus bovinus

Collybia butyracea medium medium

$54.6 \quad 46.7$

$42.7 \quad 42.2$

12.9. 24.3

$53.3 \quad 22.6$

$42.4 \quad 16.9$

$36.4 \quad 36.2$

$\begin{array}{ll}1.5 & 3.7\end{array}$

$26.8 \quad 33.5$

$1.0 \quad 5.4$

$48.7 \quad 36.7$

$43.8 \quad 32.4$

$8.8 \quad 24.5$

$1.3 \quad 8.2$

- $\quad 12.1$

$\begin{array}{ll}1.8 & 6.9\end{array}$

$0.8 \quad 2.6$

$3.9 \quad 4.8$

$6.0 \quad 28.0$

$57.4 \quad 50.2$

$4.5 \quad 13.4$

$0.7 \quad 2.5$

$1.0 \quad 1.9$
Reusser's Modess'

the suspension was inoculated into $80 \mathrm{ml}$ of the medium in a $250 \mathrm{ml}$ Erlenmeyer flask. The flasks were incubated in a rotary shaker $(200 \mathrm{rpm})$ at $28^{\circ} \mathrm{C}$. Incubation was continued until a considerable amount of rapidly growing mycelium had developed. During the incubation the volume of the medium was controlled by adding distilled water to compensate for evaporation losses. The mycelium was separated by Büchner-filtration, and was then dried to constant weight. Table 2 shows the efficiency of submerged growth expressed as grams of mycelium per 100 grams reducing sugar.

The results clearly indicated that several of the species included in this experiment grow too slowly to be useful for submerged mycelium production. The growth rate seemed to depend on the medium as well as on the species. However, both the media emploved are commonly used in the submerged cultivation of fungi. In either or both of the media the following ten species yielded mycelium to an amount higher than $25 \%$ of the weight of the utilized sugar and might thus be worth further attention: Cantharellus cibarius, Hyprophoropsis aurantiaca, Suillus 
bovinus, S. variegatus, S. grevillei, Leccinum testaceoscabrum, Armillariella mellea, Lyophyllum loricatum, Kuehneromyces mutabilis and Cortinarius hemitrichus.

\section{Amino acid content}

For the production of mycelium for amino acid analysis the fungi were grown in submerged culture in 2 liter fermentors which contained 1 liter medium. The temperature was $28^{\circ} \mathrm{C}$, agitation $280 \mathrm{rpm}$ and the aeration rate was $1 \mathrm{l}$ air $/ \mathrm{min} / \mathrm{l}$ medium. Although the first experiments had shown that Reusser's medium would not be optimal for all the test organisms this medium was used in these experiments because its composition is exactly defined. The first cultivations were made with the species which had the greatest yield coefficients in the sugar consumpiton experiments. In addition mycelia of those species for which fruiting bodies were available were also produced.

The inocula were made from two weeks old stationary cultures of the corresponding fungi. The mycelia were washed with water, broken with Ultra-Turrax and suspended in sterile water. These suspensions were used as inocula. The inocula were made visually as similar in density as possible. The growth was followed by taking twice a week a sample for sugar and ammonium nitrogen determinations (Grossfeld 1935, Conway 1957). The cultivation was considered finished when all the sugar was consumed. The grown mycelium was separated by Büchner filtration and dried at room temperature. The dry mycelium was ground to fine powder and the determinations of moisture and ash content (A.O.A.C. $13004,13006,1960$ ) as well as of nitrogen content (WILSON \& WII son, 1960) were made from the powder. The total protein content was calculated by $\mathrm{m}_{1} \mathrm{l}$. tiplication of the nitrogen value obtained by the micro-Kjeldahl method by 6.25 . Two species, Collybia dryophila and Paxillus involutus were cultivated in Erlenmeyer flasks in a rotary shaker because the culture in fermentors did not succeed due to contamination.

Table 3. Growth of the mycelia in submerged culture and comparison of the main constituents of the mycelium to the corresponding figures for the fruiting bodies.

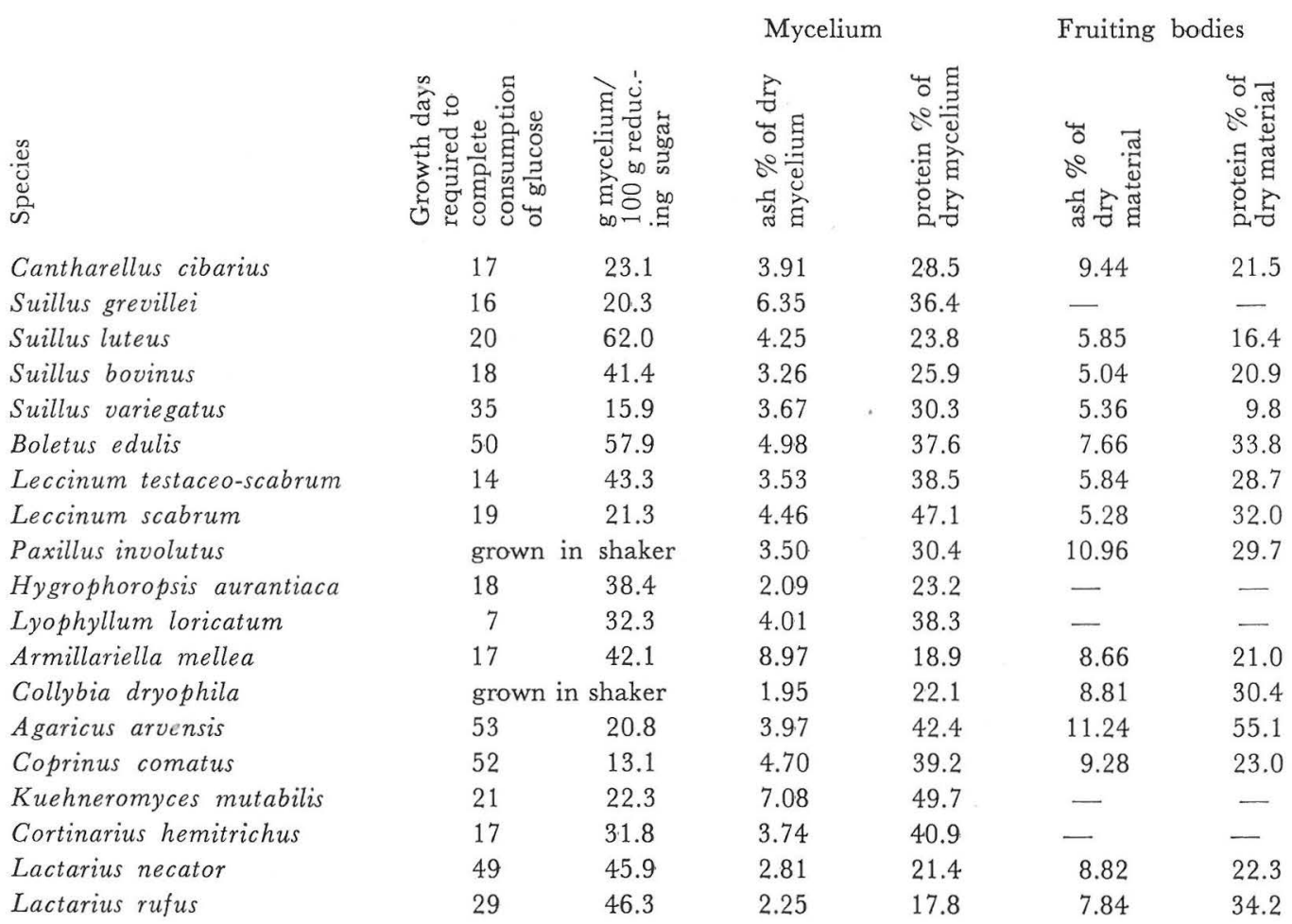


The growth of the mycelia is presented in Table 3 where the main composition of the mycelia is also compared with the corresponding data for the fruiting bodies. The results show that the growth rate of the fungi was very low. Compared with microorganisms grown in submerged culture even the shortest cultivation time with Lyophyllum loricatum, i.e. seven days, must be considered far too long. The average growth time in the medium used was 27 days. The average protein content in the mycelia $(32.2 \%)$ cannot be regarded as high but it was higher than in corresponding fruiting bodies $(27.1 \%)$.

The amino acid determinations were carried out in the following way: The dry powdered preparation of either mycelium or fruiting bodies was heated at $103^{\circ} \mathrm{C}$ to constant weight and $100 \mathrm{mg}$ of this material was weighed into $100 \mathrm{ml}$ of $6-\mathrm{n}$ $\mathrm{HCl}$. Nitrogen gas was bubbled through the solution before hydrolysis. The hydrolysis was made under reflux at $180^{\circ} \mathrm{C}$ and nitrogen was conducted into the vessel through the condenser. After hydrolysis the solution was filtered to remove humin and the hydrocloric acid was removed in
Rotawapor evaporator at $40^{\circ} \mathrm{C}$. Distilled water was added and evaporated until the $\mathrm{pH}$ of the solution was about 2. One drop of 30\% $\mathrm{H}_{2} \mathrm{O}_{2}$ and some ml:s of water were added to the dry amino acids to oxidize cysteine to cystine and the solution was allowed to stand for one hour at room temperature. The amino acids were diluted with $12.5 \%$ sucrose solution, the $\mathrm{pH}$ was adjusted to $1.9-2.1$ and the final volume of the solution was $25 \mathrm{ml}$, one $\mathrm{ml}$ of which was analyzed by Technicon Auto Analyzer.

There are notes in the literature on losses of amino acids during hydrolysis, but, on the other hand, according to a number of investigators valine will not be liberated at the same time with other amino acids. To obtain reliable results the mushroom material was hydrolyzed for different periods of time, 12, 20, 24 and 72 hours. After 12 hours hydrolysis only $\alpha$ - $\varepsilon$-diaminopimelic acid was released quantitatively. There was no evident difference in the amino acid composition of the material hydrolyzed for 20 and 24 hours, and the 20 hours hydrolysis was chosen as the zero time. No rise in the valine content occured after 72 hours hydrolysis even if a metal catalyst was used, but

Table 4. Amino acid composition of Leccinum scabrum, Cantharellus cibarius and Armillariella mellea and the average composition of the amino acids of the mycelium and the fruiting body preparations investigated. Amino acids are given as grams per 16 gram protein nitrogen.

\begin{tabular}{|c|c|c|c|c|c|c|c|c|}
\hline \multirow[t]{2}{*}{ Amino acid } & \multicolumn{2}{|c|}{ Leccinum scabrum } & \multicolumn{2}{|c|}{$\begin{array}{c}\text { Cantharellus } \\
\text { cibarius }\end{array}$} & \multicolumn{2}{|c|}{$\begin{array}{c}\text { Armillariella } \\
\text { mellea }\end{array}$} & \multicolumn{2}{|c|}{$\begin{array}{c}\text { Amino acids } \\
\text { average }\end{array}$} \\
\hline & fr. body & myc. & fr. body & myc. & fr. body & myc. & fr. body & myc. \\
\hline Aspartic acid & 6.88 & 6.89 & 7.04 & 8.32 & 10.09 & 6.52 & 7.30 & 7.19 \\
\hline Threonine & 3.81 & 3.51 & 3.21 & 5.27 & 4.70 & 4.33 & 4.02 & 4.28 \\
\hline Serine & 3.59 & 3.58 & 3.40 & 4.14 & 5.70 & 3.99 & 3.92 & 4.07 \\
\hline Glutamic acid & 11.88 & 11.47 & 10.24 & 10.73 & 14.52 & 7.51 & 11.03 & 9.65 \\
\hline Proline & 3.27 & 3.55 & 2.79 & 3.76 & 3.84 & 2.79 & 3.70 & 3.80 \\
\hline Glycine & 5.55 & 3.94 & 3.24 & 4.33 & 3.96 & 2.96 & 4.27 & 3.85 \\
\hline Alanine & 6.31 & 5.78 & 3.85 & 5.57 & 2.83 & 4.05 & 4.62 & 4.94 \\
\hline Valine & 0.27 & 0.23 & 0.63 & 1.57 & 0.36 & 0.53 & 0.53 & 0.31 \\
\hline Cystine & 4.39 & 4.93 & 3.56 & 5.04 & 5.17 & 3.98 & 4.41 & 4.82 \\
\hline Methionine & 0.30 & 0.88 & 0.80 & 1.00 & - & - & 0.24 & 0.34 \\
\hline$\alpha-\varepsilon$-diaminopimelic acid & 18.83 & 9.76 & 15.85 & 12.61 & 11.86 & 10.47 & 14.70 & 13.43 \\
\hline Isoleucine & 2.51 & 7.36 & 5.42 & 5.47 & 4.65 & 5.74 & 3.32 & 5.08 \\
\hline Leucine & 3.57 & 6.11 & 4.96 & 6.67 & 5.57 & 5.18 & 4.85 & 5.89 \\
\hline Tyrosine & 1.36 & 2.85 & 1.95 & 2.79 & 2.76 & 2.19 & 2.51 & 2.73 \\
\hline Phenylalanine & 2.87 & 3.46 & 2.67 & 3.02 & 1.76 & 2.75 & 2.60 & 3.10 \\
\hline$\gamma$-aminobutyric asid & 0.59 & 0.07 & 0.56 & 0.60 & 0.78 & 2.82 & 1.59 & 1.13 \\
\hline Ammonia $\left(\mathrm{NH}_{4}\right)_{2} \mathrm{SO}_{4}$ & 11.12 & 10.36 & 13.54 & 8.13 & 10.02 & 18.86 & 12.63 & 10.62 \\
\hline Ornithine & 0.93 & 0.09 & 3.93 & 0.38 & 0.40 & 0.40 & 0.64 & 0.30 \\
\hline Lysine & 3.68 & 4.31 & 3.55 & 5.34 & 4.44 & 4.43 & 3.88 & 4.80 \\
\hline Tryptophan & 1.46 & 1.63 & 1.28 & 3.12 & 1.71 & 3.24 & 1.79 & 2.19 \\
\hline Histidine & 2.58 & 2.61 & 2.26 & 2.62 & 1.91 & 2.23 & 2.49 & 2.54 \\
\hline Arginine & 4.73 & 6.19 & 5.20 & 4.87 & 5.31 & 5.05 & 5.04 & 5.01 \\
\hline
\end{tabular}


Table 5. The range of variation in the amounts of amino acids in the protein of different fungi compared to the $F A O$ recommendations, amino acids $\mathrm{g} / 16 \mathrm{~g}$ protein nitrogen.

\begin{tabular}{|c|c|c|c|}
\hline Amino acid & $\begin{array}{l}\text { Fruiting } \\
\text { body }\end{array}$ & Mycelium & $\begin{array}{l}\text { FAO } \\
\text { comm- } \\
\text { end- } \\
\text { ations }\end{array}$ \\
\hline Aspartic acid & $6.06-10.09$ & $2.66-9.92$ & \\
\hline Threonine & $2.07-5.23$ & $1.83-5.32$ & \\
\hline Serine & $2.57-5.10$ & $2.10-5.24$ & \\
\hline Glutamic acid & $6.52-15.31$ & $3.41-13.72$ & \\
\hline Pyroline & $2.76-5.44$ & $2.69-5.75$ & \\
\hline Glycine & $3.32-5.55$ & $1.96-4.70$ & \\
\hline Alanine & $2.83-6.31$ & $3.82-5.78$ & \\
\hline Valine & $0-0.80$ & $0-1.57$ & 4.2 \\
\hline Cystine & $3.47-5.78$ & $1.66-5.87$ & \\
\hline Methionine & $0-0.80$ & $0-1.08$ & 2.2 \\
\hline $\begin{array}{l}\alpha-\varepsilon \text {-diamino- } \\
\quad \text { pimelic acid }\end{array}$ & $6.93-21.21$ & $5.05-54.35$ & \\
\hline Isoleucine & $0-6.39$ & $0 \quad-14.13$ & 4.2 \\
\hline Leucine & $0-8.82$ & $2.01-8.09$ & 4.8 \\
\hline Tyrosine & $0-4.62$ & $1.12-3.86$ & \\
\hline Phenylalanine & $0-3.64$ & $0-3.86$ & \\
\hline $\begin{array}{l}y \text {-aminobutyric } \\
\text { acid }\end{array}$ & $0.33-4.69$ & $0.07-2.67$ & \\
\hline Ammonia & $2.18-26.26$ & $5.95-15.95$ & \\
\hline Ornithine & $0-3.93$ & $0-1.09$ & \\
\hline Tryptophan & $1.32-3.17$ & $1.24-3.72$ & 1.4 \\
\hline Lysine & $3.31-6.14$ & $1.35-8.39$ & 4.2 \\
\hline Histidine & $1.91-3.44$ & $0.91-3.44$ & \\
\hline Arginine & $3.31-6.77$ & $1.61-8.39$ & \\
\hline
\end{tabular}

the amounts of cystine and isoleucine increased and the amount of increase was constant. The amount of aumonia atso increased as a result of the destrunction of labile amino acids. After 72 hours hydrolysis losses of aspartic acid, threonine and serine occured. In the final results all the values are extrapolated to the zero time. Because of the complete destruction of tryptophan during the acid hydrolysis it was determined separately employing the enzymatic method described by SpIEs (1967), which is based on the use of pronase (Calbiochem). The selected methods were maintained constant throughout all the analyses and every determination of amino acids was made immediately after hydrolysis to avoid losses which occur in solutions.

Because it seems purposeless to describe in detail the amino acid composition of 18 different mycelia and 14 preparations of fruiting bodies, three species are chosen to give a representative picture of the amino acid composition. The fruiting bodies of these species are commonly used as food and the experience of their adaptation to submerged cultivation has been satisfactory in the authors' experiments. The amino acid composition of the fruiting bodies and the mycelia of Leccinum scabrum, Cantharellus cibarius and Armitlariella mellea and the average amino acid composition of the fungi investigated are presented in Table 4 (a corresponding comparison of the amino acid contents of the mycelium and fruiting bodies of Boletus luteus is presented in the accompanying paper; Hattula \& Gyllenberg, 1969). The range of variation in the amounts of amino acids considering all the fungi investigated as compared to the FAO recommendations are presented in Table 5 .

The present results show that the amino acid composition in different species is very similar in the mycelium and the fruiting body, respectively. The main component is ninhydrinpositive $\alpha$ - $\varepsilon$-diaminopimelic acid which is not known to be of nutritional value. All the essential amino acids are present in most of the species but the amounts of valine and methionine are very small. The small amonut of methionine in microbial protein is well known but the small amount of valine seems to be characteristic of Finnish fungi. There are, however, very few species of fungi in which other essential amino acids than methionine and/or valine are lacking. The fruiting body of Lactarius necator contains no valine, methionine, isoleucine and phenylalanine but in the corresponding mycelium only methionine is lacking. There occurs in the fruiting body of this fungus more than $50 \%$ of $\alpha$ - $\varepsilon$-diaminopimelic acid as compared with the total amount of amino acids. If the average contents of the essential amino acids are compared to the FAO recommendations only valine and methionine remain both in the mycelia and in the fruiting bodies below the limits defined. The amount of cystine in the Finnish fungi is unusually high. Because cystine can substitute for methionine up to $80 \%$ in the diet the low valine content seems to constitute the only real amino acid deficiency of the fungi investigated. 


\section{SUMMARY}

Out of 33 species of fungi only ten were found to adapt easily to submerged growth. However, these organisms, too, required as a rule 14 day or more for a complete utilization of 4 per cent sugar in a synthetic medium. The highest yield coefficient for mycelium production ( $\mathrm{g}$ mycelium per $100 \mathrm{~g}$ consumed sugar) among these fungi was 57 (Cortinarius hemitrichus) whereas the highest protein content in dry mycelium was $49.7 \%$ (Kuehneromyces mutabilis). The protein content of the mycelia produced in submerged culture was on the average somewhat higher than the corresponding figure for the fruiting bodies of the same fungi. The amino acid composition of the protein was in general the same in corresponding preparations of mycelium and fruiting bodies. Except for valine and methionine fungal protein seems to be a satisfactory source of essential amino acids.

\section{REFERENCES:}

Association of Official Agricultural Chemists, 1960: Ninth edition A.O.A.C., P.O. Box B, Franklin Station, Washington 4 D.C., 158.

Conway, E. J., 1957: Microdiffusion analysis, 4th edition, Crosby Lockwood and Son Ltd., London, 465.

FAO Nutritional Studies No. 16, 1957: Food and Agricultural Organization of the United Nations, Rome.

Grossfeld, J., 1935: Kohlenhydrate in Handbuch der Lebensmittelchemie, ed. A. Böhmer, Springer Verlag, Berlin III, 2, 866-868.

Hattula, M. L. \& H. G. Gyllenberg, 1969: Protein and fat composition and vitamin content of Boletus luteus mycelium produced in submerged culture. Karstenia 9, 46-50.

Humfeld, H., 1948: The production of mushroom mycelium (Agaricus campestris) in submerged culture, Science, 107, 373.

Humfeld, H., 1952: Production of mushroom mycelium, U.S. Patent 2618000.

Humfeld, H. \& T. F. Sugihara, 1949: Mushroom mycelium production by submerged propagation, Food Technol., 3, 355-356.

Humreld, H. \& T. F. Sugrhara, 1952: The nutrient requirements of Agaricus campestris grown in submerged culture, Mycologia, 44, 605-620.

Litchrield, J. H.: 1967 a: Submerged culture of mushroom mycelium, Microbial Technology, Reinhold Publishing Corporation, New York, Amsterdam, London, 107-144.
Litchireld, J. H., 1967 b: Submerged culture of Mushroom mycelium, Food Technol., 21, $55-57$.

Litchfield, J. H., R. C. Overbeck \& R. S. Davidson, 1963: Factors affecting the growth of morel mushroom mycelium in submerged culture, Agr. Food Chem., 11, 158-162.

Modess, O., 1941: Zur Kenntniss der Mykorrhizabildner von Kiefer und Fichte, Sym.bot. upsal., $\mathrm{V} 1: 1 \quad 16$

Moser, Meinhard, 1967: Die Röhrlinge und Blätterpilze (Agaricales). In: Helmut Gams: Kleine Kryptogamenflora, Band II b/2 (Basidiomyceten II. Teil). Gustav Fischer Verlag, Stuttgart 433 pp., 429 figs. in 13 pls.

Reusser, F., I. F. T. Spencer \& H. R. Sallans, 1958: Protein and fat content of some mushrooms grown in submerged culture, Appl. Microbiol., 6: 1-4.

SpIEs, J. R., 1967: Determination of tryptophan in proteins, Anal. Chem., 39, 1412-1416.

Sugmiara, T. F. \& H. Humfeld, 1954: Submerged culture of the mycelium of various species of mushroom, Appl. Microbiol., 2, $170-$ 172.

Szuecs, J., 1956: Mushroom culture, U.S. Patent 2761246 .

Wilson, G. L. \& D. W. WiLson, 1960: Comprehensive Analytical Chemistry, Elsevier Publishing Company, Amsterdam, London, New York, Princeton, 505. 